\title{
Updates for the IVF Good Practice
}

\author{
Howaida Hashim ${ }^{1,2,3,4,5 *}$ \\ ${ }^{1}$ Senior Embryologist, Saudi Arabia \\ ${ }^{2}$ Director, Middle East Fertility Society Embryologist Interest Group, Saudi Arabia \\ ${ }^{3}$ Director, IVF Laboratory, Saudi Arabia \\ ${ }^{4}$ Deputy Head, IVF Unit, Saudi Arabia \\ ${ }^{5}$ Dr Erfan \& Bagedo General Hospital, Saudi Arabia
}

Submission: August 13, 2018; Published: August 17, 2018

*Corresponding author: Howaida Hashim, Senior Embryologist, Saudi Arabia, Email: hhashimh@aol.com

Abbreviations: RPL: Recurrent Pregnancy Loss; PGS: Preimplantation Genetic Screening; PR: Pregnancy Rate; LBR: Life Birth Rate; CMR: Clinical Miscarriage Rate

\section{Opinion}

Several guidelines had been issued describing the minimal requirements of the IVF laboratory. The aim of these guidelines is to support the IVF laboratory staff in the implementation of quality system including all laboratory procedures, quality control and quality assurance.

40 years passed since the born of the first IVF baby, numerous procedures had been added in the field of assisted conception, such as cryopreservation, micromanipulation, assisted hatching and preimplantation screening.... and more.

A new guideline should be assembled, and the recommendations should be thoroughly discussed describing the day to day practice in IVF laboratory, including identification of patients, handling of cells and tissues, classification and detecting consumables used and needed, implementing backup system preventing or minimizing any damages of equipment's and keeping checklists and patients' records completed.

One of the very important issues that should be included within the guidelines, is the counseling for patients suffering from recurrent pregnancy loss (RPL) and going for preimplantation genetic screening (PGS) for this reason [1-9].

Patients need to be counseled for the expected pregnancy rate (PR) or life birth rate (LBR) in cases when they go for PGS due to RPL where LBR will not be increased and the clinical miscarriage rate (CMR) will not be less. A lot of scientific papers now showing that when PGS is used in treating cases of RPL, where the utilization of the treatment is usually based on the selection of the euploid embryos for transfer, will not result in lower CMR or higher LBR.
In fact, when we make our statistics, all attempts of PGS should be included, counting cycles in which PGS were intended but canceled due to insufficient embryo quality for biopsy and cycles that did not proceed to embryo transfer because there were no "healthy" embryo(s) for transfer following the test, should be added as well. However, patient expectations must be managed for a possible cycle cancellation rate.

In conclusion, counseling patients being a very important subject and it is included within the IVF guidelines. Also counseling patients suffering from pregnancy loss and doing PGS for that reason only should be counseled as well not only with the success rates of PGS per euploid embryo transferred, but also LBR per initiated PGS cycle should be included and they should be told that, in their case, PGS may not accelerate their time to conception [10-17].

\section{References}

1. Brigham SA, Conlon C, Farquharson RG (1999) A longitudinal study of pregnancy outcome following idiopathic recurrent miscarriage. Human Reprod 14(11): 2868-2871.

2. Guideline on the management of recurrent pregnancy loss.

3. Forman EJ, Hong KH, Ferry KM, Tao X, Taylor D, et al. (2013) In vitro fertilization with single euploid blastocyst transfer: a randomized controlled trial. Fert Steril 100(1): 100-107.

4. Hodes-Wertz B, Grifo J, Ghadir S, Kaplan B, Laskin C, et al. (2012) Idiopathic recurrent miscarriage is caused mostly by aneuploid embryos. Fert Steril 98(3): 675-680.

5. Lachmi-Epstein A, Mazor M, Bashiri A (2012) Psychological and mental aspects and 'tender loving care' among women with recurrent pregnancy losses. Harefuah 151(11): 633-637.

6. Marquard K, Westphal LM, Milki AA, Lathi RB (2010) Etiology of recurrent pregnancy loss in women over the age of 35 years. Fertil Steril 94(4): 1473-1477. 
7. Murugappan G, Ohno M, Lathi RB (2015) Cost-effectiveness analysis of Preimplantation genetic screening and in vitro fertilization versus expectant management in patients with unexplained recurrent pregnancy loss. Fertil Steril 103(5): 1215-1220.

8. Perfetto CO, Murugappan G, Lathi RB (2015) Time to next pregnancy in spontaneous pregnancies versus treatment cycles in fertile patients with recurrent pregnancy loss. Fertil Res Pract 1: 5.

9. Shahine L, Lathi RB (2014) Embryo selection with preimplantation chromosomal screening in patients with recurrent pregnancy loss. Semin Reprod Med 32: 93-99.

10. Shahine L, Lathi RB (2015) Recurrent pregnancy loss: evaluation and treatment. Reprod Endocrinol 42(1): 117-134.

11. Stephenson M (1996) Frequency of factors associated with habitual abortion in 197 couples. Fertil Steril 66(1): 24-29.

12. Stephenson M, Kutteh W (2007) Evaluation and management of recurrent early pregnancy loss. Clin Obstet Gynecol 50(1): 132-145.
13. Stirrat GM (1990) Recurrent miscarriage. Lancet 336(8716): 673-675.

14. Jauniaux E, Farquharson RG, Christiansen OB, Exalto N (2006) Evidence-based guidelines for the investigation and medical treatment of recurrent miscarriage. Hum Reprod 21(9): 2216-2222.

15. The Practice Committee of the American Society for Reproductive Medicine (2012) Evaluation and treatment of recurrent pregnancy loss: a committee opinion. Feril Steril 98(5): 1103-1111.

16. Regan L, Backos M, Rai R (2011) The Royal College of Obstetricians and Gynecologists. The RCOG Green-Top Guideline No. 17. The Investigation and Treatment of Couples with Recurrent First-trimester and Secondtrimester Miscarriage.

17. Viaggi CD, Cavani S, Malacarne M, Floriddia F, Zerega G, et al. (2013) First-trimester euploid miscarriages analysed by array-CGH. J Appl Genet 54(3): 353-359.

\section{Your next submission with Juniper Publishers will reach you the below assets}

- Quality Editorial service

- Swift Peer Review

- Reprints availability

- E-prints Service

- Manuscript Podcast for convenient understanding

- Global attainment for your research

- Manuscript accessibility in different formats

(Pdf, E-pub, Full Text, Audio)

- Unceasing customer service

Track the below URL for one-step submission https://juniperpublishers.com/online-submission.php 